\title{
HONORÉ DE BALZAC, Papà Goriot
}

\section{Marco Stupazzoni}

\section{OpenEdition \\ Journals}

\section{Edizione digitale}

URL: https://journals.openedition.org/studifrancesi/45234

DOI: $10.4000 /$ studifrancesi.45234

ISSN: 2421-5856

\section{Editore}

Rosenberg \& Sellier

\section{Edizione cartacea}

Data di pubblicazione: 1 août 2021

Paginazione: 385

ISSN: 0039-2944

\section{Notizia bibliografica digitale}

Marco Stupazzoni, «Honoré de balzac, Papà Goriot», Studi Francesi [Online], 194 (LXV | II) | 2021, online dal 01 septembre 2021, consultato il 15 octobre 2022. URL: http://journals.openedition.org/studifrancesi/ 45234 ; DOI: https://doi.org/10.4000/studifrancesi.45234

Questo documento è stato generato automaticamente il 15 octobre 2022.

\section{(c)}

Creative Commons - Attribuzione - Non commerciale - Non opere derivate 4.0 Internazionale - CC BYNC-ND 4.0

https://creativecommons.org/licenses/by-nc-nd/4.0/ 


\title{
HONORÉ DE BALZAC, Papà Goriot
}

\author{
Marco Stupazzoni
}

\section{NOTIZIA}

HONORÉ DE BALZAC, Papà Goriot, Saggio introduttivo di P.P. Trompeo, traduzione di R.

Mucci, Roma, Edizioni Theoria, 2019, x-245 pp.

1 Sia la traduzione di Renato Mucci sia lo studio di Pietro Paolo Trompeo: Chiose a Balzac (pp. III- x) risalgono al 1950 (Roma, Gherardo Casini Editore).

2 Balzac, scrive Trompeo, è da considerarsi veramente come l'Omero della borghesia francese, egoista, affarista ma anche eroica? I lati, per così dire, deteriori dei romanzi balzachiani non possono certo essere misconosciuti: «un non so che di falso», osserva Trompeo, «sembra insidiare la vita stessa dei personaggi» e «quanto più il romanziere li lancia nel vortice dell'azione e li sospinge di avventura in avventura, tanto più essi ci appaiono, artisticamente, impotenti ad agire» (pp. IV-V). È il caso, ad esempio, del Père Goriot, dove «il precipitarsi dell'azione nel melodramma, o comunque nella frettolosa elaborazione retorica e pietistica, contrasta con la possente bellezza di tutta la prima parte del romanzo con il quadro goyesco della pensione Vauquer e dei suoi abitanti» (p. v). A giudizio del critico, in Balzac «l'ambientista, il ritrattista e lo storico si lasciano addietro di gran lunga il narratore-inventore» (ibidem). Il contrasto tra il narratoreinventore e il moralista-ritrattista si avverte, tranne rare eccezioni, nell'intera opera balzachiana: l'aver tracciato il quadro storico totale della società francese del primo Ottocento non esclude, tuttavia, quel «côté visionnaire» che Baudelaire riconosceva come il segno distintivo di Balzac e dal quale non è possibile prescindere. Come Tacito $\mathrm{e}$ Saint-Simon, Balzac ci ha dimostrato che i visionari «possono veder meglio dei professori di storia» (p. x). 